\title{
SLIT3 Gene
}

National Cancer Institute

\section{Source}

National Cancer Institute. SLIT3 Gene. NCI Thesaurus. Code C126788.

This gene plays a role in the regulation of cell migration. 